\title{
Climate Finance and Its Governance: Moving to a Low Carbon Economy through Socially Responsible Financing?
}

Benjamin J. Richardson

Osgoode Hall Law School of York University

Source Publication:

International and Comparative Law Quarterly. Volume 58, Issue 3 (2009), p. 597-626.

Follow this and additional works at: https://digitalcommons.osgoode.yorku.ca/scholarly_works (c) (i) $(9)$

This work is licensed under a Creative Commons Attribution-Noncommercial-No Derivative Works 4.0 License.

\section{Recommended Citation}

Richardson, Benjamin J. "Climate Finance and Its Governance: Moving to a Low Carbon Economy through Socially Responsible Financing?" International and Comparative Law Quarterly 58.3 (2009): 597-626.

This Article is brought to you for free and open access by the Faculty Scholarship at Osgoode Digital Commons. It has been accepted for inclusion in Articles \& Book Chapters by an authorized administrator of Osgoode Digital Commons. 


\title{
CLIMATE FINANCE AND ITS GOVERNANCE: MOVING TO A LOW CARBON ECONOMY THROUGH SOCIALLY RESPONSIBLE FINANCING?
}

\author{
BENJAMIN J RichaRDSON*
}

\begin{abstract}
Climate finance' is becoming an important feature of the emerging legal and policy regimes to address global warming. However, the current approach largely confines the financial sector to a transactional agent to mobilise capital for clean energy and to broker emission allowance trading. The sector's potential to leverage more sweeping positive changes in the economy as sought historically through the movement for socially responsible investment (SRI) has been insufficiently acknowledged. Indirectly, by regulating greenhouse gases the legal system is helping to create a business case for investors to respond to climate change threats. However, the potential contribution of SRI to address climate change problems more comprehensively is presently limited owing to inadequate governance frameworks, as well the sector's increasing abandonment of its traditional ethical agenda.
\end{abstract}

\section{INTRODUCTION}

To what extent, and how, can financial markets contribute to climate policy goals? Amidst the mounting international urgency to combat global warming, the financial sector has become an increasingly prominent stakeholder. The Kyoto Protocol's inclusion of various economic mechanisms to achieve cost effective reductions of greenhouse gas (GHG) emissions, created a framework for financial institutions such as banks and pension funds to play a seminal role in the transition to a low carbon economy. ${ }^{1}$ They would be able to act as brokers for carbon trading, and as financiers for clean development and climate adaptation. Until recently, however, another role of financial markets has been somewhat overlooked in the climate policy debates. It is the movement for socially responsible investment (SRI).

Rather than limiting financial institutions to mere transactional agents in climate finance, SRI envisions a much more active and enlightened role for

* Osgoode Hall Law School, York University, Canada. brichardson@osgoode.yorku.cg

1 Kyoto Protocol to the Framework Convention on Climate Change (1998) 37 ILM 22. 
them. Traditionally, SRI has expected financiers to act as ethical investors, who prioritise socially just and ecologically sustainable development over the maximisation of financial returns. ${ }^{2}$ In other words, the financial sector should act in the public interest rather than merely for its own economic self-interest. By this approach, SRI promises a radical path to a low carbon world, whereby the financial sector may exploit its economically strategic position to leverage positive changes in corporate behaviour. If successful, SRI can overcome the limitations and gaps in official climate regulation by pushing for early corporate action to reduce GHG emissions.

However, SRI is not a textbook manual for social responsibility, but rather a fluid discourse open to diverse interpretations and practices. In recent years, particularly since 2000 , that discourse has changed profoundly. ${ }^{3}$ Many SRI actors have jettisoned pretensions to invest solely on 'ethical' grounds; instead, they are motivated primarily by a 'business case' whereby social and environmental problems, including global warming, are addressed on the basis of the relative financial risks and opportunities to the investor. A second important transformation in SRI is the propagation of an array of codes of conduct and other governance standards for responsible finance. Several of these regimes specifically target climate change issues, such as the Carbon Disclosure Project. In general, this trend in SRI governance has tended to reinforce the drift to the business case approach.

This article assesses the contribution of SRI to climate finance and the transition to a low carbon economy. Taking a comparative and international perspective of the subject, it examines in particular the relationship between SRI and the mechanisms for governance of climate finance. This article argues that international financial markets are presently unlikely to be the vanguard of change to a low carbon world. This is for primarily two reasons. First, the shift to a business case approach to SRI has blunted its pretences to be a vehicle for radical reform. Secondly, although SRI arose to provide a form of surrogate market regulation, compensating for the lacunae and weaknesses of official regulation, its dependence on the state to create legal standards conducive to responsible conduct in the area of climate finance is increasingly evident. While the article does not seek to explain in detail how SRI could be legally reformed to enable the financial sector to play a more effective role in responding to climate change- - a topic of great length requiring a further essay-it provides insights into future directions.

${ }^{2}$ See S Meeker-Lowry, Economics as if the Earth Really Mattered: A Catalyst Guide to Socially Conscious Investing (New Society Publishers, Gabriola Island, Canada, 1988); S Bruyn, The Field of Social Investment (Cambridge University Press, Cambridge, 1987).

${ }^{3}$ On recent changes to SRI, see C Krosinsky and N Robins (eds), Sustainable Investing: The Art of Long Term Performance (Earthscan, London 2008). 


\section{A. An Emerging Issue}

Climate change will be the most complex and expensive environmental problem humanity has ever had to address. According to the Stern Review commissioned by the British Government, the cost of business-as-usual, of not taking immediate action to mitigate climate change, will in years to come likely amount to between 5 to 10 per cent of world gross domestic product (GDP) each year, but only 1 to 2 per cent of GDP if we act now. ${ }^{4}$ The Stern report, however, sanguinely assumes that climate change can be managed without any fundamental change to our economy, the market system, and the concomitant priority given to economic growth. Other commentators such as Monbiot, Flannery, and Homer-Dixon predict much severer challenges and costs in kicking the carbon economy. ${ }^{5}$ Credible government policy measures to reduce emissions rapidly have yet to be advanced, and the political will in many countries to force change is muted. ${ }^{6}$

In the present era of finance capitalism-an economic system dominated by the financial sector and involving the propagation of a complex system of banking services, securities markets, and other financial instruments ${ }^{7}$ - the finance sector will likely play a central role in climate policy. It can help to price climate risks and facilitate investment in renewable energy and efficient technologies. ${ }^{8}$ The investment community increasingly perceives some action on climate change as in its self-interest, for it poses risks to the value of their investment portfolios or their borrowers' solvency through tightening regulations, impairment of physical assets, and reduced income. ${ }^{9}$ A report by the International Finance Corporation assessed climate change as 'a particularly powerful catalyst' for the incorporation of environmental factors into

4 N Stern, Stern Review on the Economics of Climate Change (HM Treasury, 2007).

${ }^{5} \mathrm{G}$ Monbiot, Heat: How to Stop the Planet Burning (HarperCollins, London, 2005); T Flannery, The Weather Makers (Atlantic Monthly Press, New York, 2006); T Homer-Dixon, The Upside of Down: Catastrophe and Renewal and the Renewal of Civilisation (Alfred A Knopf, New York, 2006).

${ }^{6}$ F Yamin and J Depledge, The International Climate Change Regime: A Guide to Rules, Institutions and Procedures (Cambridge University Press, 2005); M Peeters and K Deketelaere (eds), EU Climate Change Policy: The Challenge of New Regulatory Initiatives (Edward Elgar, Cheltenham, 2006), D Zillman et al (eds), Beyond the Carbon Economy (Oxford University Press, Oxford, 2008).

7 See G Edwards, The Evolution of Finance Capitalism (Longmans, Green, and Company, 1938); J Froud, A Leaver and K Williams 'New Actors in a Financialised Economy and the Remaking of Capitalism' 12 New Political Economy 339 (2007).

${ }^{8} \mathrm{~S}$ Labatt and R White, Carbon Finance: The Financial Implications of Climate Change (John Wiley, 2007).

9 A Shell and M Krantz, 'Global Warming a Hot Spot for Investors' USA Today Online (27 February 2007); J Leggett, 'Climate Change and the Banking Industry: A Question of Both Risk and Opportunity' (1996) 179 Bankers Magazine 25. 
investment decision-making. ${ }^{10}$ Some analysts predict 'climate change due diligence... will soon become an indispensable facet of inquiry in any transaction'. ${ }^{11}$

Although the financial sector is publishing numerous studies that warn of the impact of global warming on its self-interest, ${ }^{12}$ so far tangible changes in investment practices are hard to discern. Financial markets continue to capitalize the fossil fuel industry heavily. The surging investment in Alberta's oil sands is one of the most controversial examples. Even many so-called SRI funds continue to hold stakes in GHG emitting firms. ${ }^{13}$ The business case for investment in fossil fuels often remains far more potent than the business case for divestment. Most fundamentally, the turmoil that swept global financial markets in late 2008 and early 2009 epitomized the deep structural failure of the financial sector to manage risks and invest with a view to the long term. ${ }^{14}$ The speculative, myopic and avaricious culture embedded in this sector, which precipitated the market turmoil, hardly provides the appropriate milieu to nurture an environmentally responsible financial community that invests for sustainable development.

Presently, the financial sector acts mainly as a transactional mechanism to allocate capital for climate mitigation and adaptation efforts. In other words, it is an intermediary, helping to facilitate investment in renewable energies, Clean Development Mechanism projects, and carbon emission trading. One such player, for instance, is the British-based Carbon Capital Markets, which buys and sells carbon allowances for companies. ${ }^{15}$ The financial sector has also pioneered voluntary trading schemes, the most successful example being the Chicago Climate Exchange (CCX). Established in 2003, the CCX is a GHG emission allowance trading hub for emission sources and offset projects in the United States (US) and a growing number of other countries including Canada, Brazil, and Mexico. ${ }^{16}$ The CCX members, who include corporate behemoths such as Ford and IBM, make voluntary commitments to reduce their GHG emissions in 2010 by 6 per cent below a baseline period of

10 International Finance Corporation (IFC), 'Who Cares Who Wins'. One Year On (IFC, 2005) 8 .

11 J Smith, 'The Implications of the Kyoto Protocol and the Global Warming Debate for Business Transactions' (2005) New York University Journal of Law and Business 511.

$12 \mathrm{~J}$ Llewellyn, The Business of Climate Change: Challenges and Opportunities (Lehman Brothers, New York, 2007); World Resources Institute (WRI) and Merrill Lynch, Energy Security and Climate Change: Investing in the Clean Car Revolution (WRI and Merrill Lynch, 2005); Worldwide Fund for Nature (WWF) and Allianz, Climate Change and the Financial Sector: An Agenda for Action (WWF and Allianz, Gland, Switzerland, 2005).

${ }^{13}$ N Lansbury, Socially Responsible Climate Change? Fossil Fuel Investments of the Socially Responsible Investment Industry in Australia (Mineral Policy Institute, 2002) 30.

${ }_{4}$ On the crisis, see G Soros, The New Paradigm for Financial Markets: The Credit Crisis of 2008 and What It Means (Public Affairs, New York, 2008); R Shiller, The Subprime Solution: How Today's Global Financial Crisis Happened, and What to Do About It (Princeton University Press, Princeton, 2008).

${ }^{16}$ See <http://www.chicagoclimatex.com $>$. 
1998-2001. ${ }^{17}$ In the retail finance markets, catering mainly to individuals, mutual funds are selling climate-friendly investment portfolios, and banks are offering 'green' home loans that take into account the energy efficiency of mortgaged properties. ${ }^{18}$

In theory, however, the long-standing movement for SRI suggests that the financial sector could play a more ambitious role on climate issues. It evolved from church-based, single-issue activism, where ethical investors eschewed ties to companies and activities deemed immoral, such as gambling, alcohol, and vulgar entertainment. From the late 1960s, the SRI movement began to embrace a wider agenda of concern for human rights, taking up cause against the Vietnam War and, later, South Africa's apartheid regime. ${ }^{19}$ Since the 1980 s, and especially since the late 1990 s, SRI has also championed environmental causes including climate change. ${ }^{20}$ The massive growth of international financial markets, fuelled in part by surging household wealth and the participation of mass society in investment schemes such as pension plans and mutual funds, has provided an opportunity for ordinary people to use their investments to promote positive social and environmental changes including stopping global warming. ${ }^{21}$ As it has matured, SRI has sought to influence financial markets through several techniques, including ethical screens (excluding assets in problematic firms), 'best-in-class' portfolios (selecting the firms that act the most responsibly relative to their peers), shareholder advocacy (using shareholder rights to advocate change within companies) and, in the banking sector, financing on preferential terms to socially or environmentally beneficial projects. Through such techniques and engagement with a widening agenda of issues, SRI seeks improvements in corporate social and environmental behaviour beyond the letter of the law. However, as this article will discuss shortly, that potential has not yet been generally reached.

\section{B. The Market and Legal Context of Climate Finance}

The threat of climate change, which should raise profound questions about the sustainability of our economic system, is hardly debated in the mainstream financial community. ${ }^{22}$ Taylor and Brown contend that we need to debate the

${ }^{17}$ Remarks, Richard Sandor. CEO, Chicago Climate Exchange (18 ${ }^{\text {th }}$ Annual SRI in the Rockies Conference, Santa Ana Pueblo, New Mexico, 3-6 November 2007).

18 United Nations Environment Program Finance Initiative (UNEPFI), Green Financial Products and Services: Current Developments and Future Opportunities in North America (UNEPFI, Geneva, 2007) 17-19.

19 R Sparkes, 'A Historical Perspective on the Growth of Socially Responsible Investment' in Rory Sullivan and Craig Mackenzie (eds) Responsible Investment (Greenleaf Publishing, Sheffield, 2006), 39.

${ }^{20}$ See M Jeucken, Sustainable Finance and Banking: The Financial Sector and the Future of the Planet (Earthscan, London, 2001); Labatt and White, above (n 1).

${ }_{21}$ S Davis, J Lukomnik and D Pitt-Watson, The New Capitalists. How Citizen Investors are Reshaping the Corporate Agenda (Harvard Business Press, Cambridge, 2006).

${ }^{22}$ See the online climate ethics network at $<\mathrm{http}: / /$ www.climateethics.org $>$. 
ethical issues raised by climate change to reach an urgently needed international consensus for action. ${ }^{23}$ They also see ethical deliberation as crucial to leading the world toward an equitable sharing of the burdens and benefits of protecting the planet, as called for in the UN Framework Convention on Climate Change (UNFCCC). ${ }^{24}$ Yet, for most investors, global warming is (at most) mainly a matter of financial risk or investment opportunity. With decision-making in financial institutions dominated by fund managers and other investment professionals focused on the 'bottom line', any notion that such institutions are a forum of enlightened ethical deliberation among climate-conscious investors would be naive.

The legal system influences the construction of these risks and investment opportunities. On the upside, the Kyoto Protocol's 'flexible' mechanisms create several market opportunities for financiers. ${ }^{25}$ They expand opportunities for lending to companies acquiring emission abatement technologies. Also, the Clean Development Mechanism and Joint Implementation sectors provide opportunities for project finance. Further, carbon emission trading creates a demand for brokerage services. Finally, climate risk assessment in equity and debt financing provides additional work for financial analysts.

On the downside, polluting industries in the oil and gas, heavy manufacturing, and transport sectors should be competitively disadvantaged by climate regulation, thereby hurting their investors. ${ }^{26}$ While such losses would concern any rational investor, they would particularly concern institutional investors having fiduciary duties to their fund beneficiaries to promote optimal financial returns. ${ }^{27} \mathrm{~A}$ guide for British pension fund trustees suggests that:

Climate risk can have a real impact on portfolio holdings. There is a growing case for trustees to attain some level of knowledge around these issues, and to take steps to mitigate any negative consequences of not taking action.

${ }^{23}$ D Brown, American Heat: Ethical Problems with the United States Responses to Global Warming (Rowman and Littlefield, Lanham, Massachusetts, 2002); P Taylor, An Ecological Approach to International Law: Responding to Challenges of Climate Change (Routledge, London and New York, 1998).

Article 3.1 (1992) 31 ILM 849.

25 J Janssen, 'Implementing the Kyoto Mechanisms: Potential Contributions by Banks and Insurance Companies' (2000) 25 Geneva Papers on Risk and Insurance 602; J Mandt, 'Managing Risk in Kyoto Projects' (1999) 1(2) Environmental Finance 23; H Hugenschmidt and J Janssen, 'Kyoto Protocol: New Market Opportunities or New Risks?' (1999) 11 Swiss Derivatives Review 22.

${ }_{26}$ World Resources Institute (WRI), Changing Oil: Emerging Environmental Risks and Shareholder Value in the Oil and Gas Industry (WRI, Washington DC, 2002).

${ }^{27}$ Fiduciary duties arise where the exercise of some discretionary power in the interests of another person gives rise to a relationship of trust. The fiduciary duties of loyalty and prudence require the trustee to manage assets wisely only on behalf the beneficiaries. On fiduciary duties and SRI, see B J Richardson, 'Do the Fiduciary Duties of Pension Funds Hinder Socially Responsible Investment?' (2007) 22(2) Banking and Finance Law Review 145. While fiduciary duties are a concept of common law systems, functionally equivalent concepts exist in some financial legislation in civil law jurisdictions. 
In line with these definitions of fiduciary responsibility, we suggest that it is consistent with fiduciary responsibility to address climate change risk. ${ }^{28}$

Regulatory risk is thus one of the most material concerns to investors, as some governments have begun to tighten controls on GHG emissions. The growing reliance on market-based policy instruments, such as carbon taxes and subsidies for clean energy investments, will affect the competitive advantage of polluters. ${ }^{29}$ Several studies also forecast that participants in emission cap-andtrade schemes will incur cash flow risks from the increased expenditure on GHG reduction measures or the purchase of emission allowances. ${ }^{30}$

This partiality to economic instruments reflects a broader evolution in environmental law worldwide, which is moving away from bureaucratic, command-and-control regulation toward 'reflexive' legal instruments perceived as more congruent with the workings of the market. ${ }^{31}$ Thus, the United Kingdom (UK), once a staunch opponent of carbon taxation, in 2001 introduced a climate change levy on non-renewable energy consumed by industry and public sector agencies. ${ }^{32}$ The UK's Climate Change and Sustainable Energy Act 2006, Canada's Clean Air and Climate Change Act 2007 and New Zealand's Climate Change (Emissions Trading and Renewable Preference) Act 2008, are among the new climate laws creating a framework for further such initiatives. Even in the US, where federal policy was largely indifferent to global warming until the election of President Barack Obama, several states have acted unilaterally. ${ }^{33}$ For instance, California's Global Warming Solutions Act 2006 caps the state's GHG emissions at 1990 levels by 2020 , and mandates a cap-and-trade system to help achieve this goal.

Litigation risks may also concern some investors. Several lawsuits initiated in North America against major GHG emitters may ignite fears of a litigation onslaught reminiscent of the anti-tobacco campaign. ${ }^{34}$ Big polluters could be

28 Mercer Investment Consulting (MIC), A Climate for Change: A Trustee's Guide to Understanding and Addressing Climate Risk (MIC, Carbon Trust, London, 2005) 18-19.

${ }^{29} \mathrm{R}$ Stavins, 'Policy Instruments for Climate Change: How Can National Governments Address a Global Problem?' (1997) University of Chicago Legal Forum 293.

${ }^{30}$ UNEPFI Climate Change Working Group, CEO Briefing. Emissions Trading (UNEPFI, Geneva, January 2004), 4; Standard and Poor's (S\&P's), Emissions Trading: Carbon Will Become a Taxing Issue for European Utilities (S\&P's, New York, 2003).

31 D Driesen, 'Economic Instruments for Sustainable Development' in B J Richardson and S Wood (eds), Environmental Law for Sustainability (Hart Publishing, Oxford, 2006) 277. On reflexive law, see G Teubner, L Farmer and D Murphy (eds), Environmental Law and Ecological Responsibility: The Concept and Practice of Ecological Self-Organisation (John Wiley and Sons, Hoboken, 1994).

32 B J Richardson and K Chanwai, 'The UK's Climate Change Levy: Is It Working?' (2003)15(1) Joumal of Environmental Law 39.

${ }^{33}$ C Carlarne, 'Climate Change Policies an Ocean Apart: EU and US Climate Change Policies Compared' (2006) 14 Penn State Environmental Law Review 435.

${ }^{34} \mathrm{~K}$ Healy and J Tapick, "Climate Change: It's Not Just a Policy Issue for Corporate Counsel-It's a Legal Problem' (2004) 29 Columbia Joumal of Environmental Law 89; J Gupta, 'Legal Steps Outside the Climate Convention: Litigation as a Tool to Address Climate Change' (2007) 16 Review of European Community and International Environmental Law 76. 
liable for damages associated with the physical effects of climate change, such as flooding, severe storm damage or droughts. In 2004, eight US states and New York City sued five of the country's largest power companies for creating a public nuisance. ${ }^{35}$ In the 2006 case of Lockyer v General Motors, ${ }^{36}$ California commenced a similar tort action against six automobile manufacturers. While some legal commentators believe that 'the probability of legal victories against global warming is low', ${ }^{37}$ they also concede that such litigation may generate substantial legal fees and costly delays to new projects. ${ }^{38}$ Climate litigation is emerging in other countries, including actions against governments in Australia ${ }^{39}$ and Canada. ${ }^{40}$

Climate change also poses both physical risks and intangible reputational risks to investments. Economic sectors dependent on stable climate conditions, such as agriculture, forestry and tourism, face physical threats. ${ }^{41}$ The oil industry itself is vulnerable, as illustrated by how Hurricane Katrina in 2005 shut down many refineries in Louisiana. The real estate finance sector is also exposed to damages from extreme weather events. ${ }^{42}$ The insurance industry, which covers many of these risks, is thus acutely exposed. ${ }^{43}$ High profile companies that disregard climate change also face reputational risks. Fossil fuel dependent corporations like ExxonMobil are often targets of consumer boycotts and shareholder pressure ${ }^{44}$ Civil society groups increasingly target financial institutions associated with such firms; a coalition of mostly US environmental groups in 2006 started a campaign that demanded major banks cease lending to coal power plants. ${ }^{45}$ In December 2008, the Bank of America agreed to one of their demands to stop financing environmentally destructive open-cut coal mining. ${ }^{46}$

${ }^{35}$ See eg State of Connecticut, et al v American Electric Power Company, et al (2005) $406 \mathrm{~F}$ Supp 2d. 265 (SDNY) (under appeal).

36 No 3:06. Civ 05755 (ND California, filed 20 September, 2006).

37 M Levinson, Liability for Climate Change (JPMorgan Chase, New York November 2006).

38 ibid 1.

39 Australian Conservation Foundation v. Minister for Planning, [2004] VCAT 2029, 23.

40 Friends of the Earth $v$ The Governor in Council and the Minister of the Environment, [2008] FC 1183.

41 See UBS, Climate Change: Beyond Whether (UBS, Zürich, 2007).

42 ISIS Asset Management, A Benchmarking Study: Environmental Credit-Risk Factors in the Pan European Banking Sector (ISIS Asset Management, 2002), 14.

${ }^{43}$ M Northrop, 'Leading by Example: Profitable Corporate Strategies and Successful Public Policies for Reducing Greenhouse Gas Emissions' (2004) 14 Widener Law Journal 21, 32.

${ }^{44}$ F Barringer, 'Environmental Groups Planning to Urge Boycott of ExxonMobil' New York Times (12 July 2005) A14. 2007).

45 J Donnelly, 'Banks are Urged not to Finance Coal Power' Boston Globe Online (16 January

${ }^{46}$ T Zeller, 'Bank of America to Stop Financing Mountaintop Mining' New York Times (4 December 2008). 
Conversely, companies that pioneer low carbon and energy efficient technologies stand to gain financially. ${ }^{47}$ Many investors, at least before the global financial crisis of late 2008 , were favouring renewable energies, ethanol production, environmentally efficient technologies, and carbon offset projects. ${ }^{48}$ Citigroup's 2007 list of 'climatic consequences companies' identified 74 companies (across 21 industries) 'that seem well positioned to benefit from these trends'. ${ }^{49}$ The creation of the Photon Photovoltaic Stock Index, ABN AMRO Biofuel Commodity Index, and the KLD Global Climate 100 Index, among various examples, enable investors to buy into a portfolio of companies in these sectors. The propagation of carbon emissions trading systems promises further lucrative spoils for financial brokers. The World Bank estimated that the value of the global carbon market reached US\$64 billion in 2007 (up from US $\$ 31$ billion in 2006), mostly associated with the European Union's GHG trading scheme. ${ }^{50}$

Yet, incongruously, the fossil fuel sector still thrives. The effusive rhetoric in the financial industry about the threat of global warming does not reflect the wider picture. The spree of investment in the world's new oil frontier, Alberta's oil sands, is just one example. ${ }^{51}$ A 2007 study by Ethical Funds of the booming oil sands industry documented that only four of the 50 companies assessed were cutting emissions. ${ }^{52}$ Only a handful were taking appropriate measures, such as factoring carbon costs into capital allocation decisions and conducting GHG emission inventories. And few had invested in renewable energy production.

Clearly, so long as fossil fuels remain a relatively cheap alternative and vested interests thwart change, SRI in the energy sector has constrained prospects. Plausibly, new policy instruments are required to create a level playing-field. A report by the World Wide Fund for Nature and the Allianz Group in 2005 advised that 'banks and investors in particular need a clear regulatory framework on climate policy which they can adapt and base their investment and lending decisions'. ${ }^{53}$ Yet, the SRI movement arose precisely as an answer to the lacunae and weaknesses of governmental regulation. When governments fail to act, as they did against South Africa's apartheid regime,

47 World Resources Institute (WRI) and the Coalition for Environmentally Responsible Economies (CERES), Questions and Answers for Investors on Climate Risk (WRI, Washington DC, 2004) 23.

48 D Berman, 'Hot for Green Investing' Financial Post (19 February 2007).

49 Citigroup, Climatic Consequences (Citigroup Research, New York 19 January 2007) 1.

${ }^{50} \mathrm{~K}$ Capoor and P Ambrosi, State and Trends of the Carbon Market 2008 (World Bank, 2008) 59.

51 R Walker, Ethical Funds Company (presentation at the Canadian Responsible Investment Conference, Montreal, 27-29 May 2007).

52 Ethical Funds Company (EFC), Head in the Sands? Climate Change Risks in Canada's Oil and Gas Sector (EFC, Vancourer, 2007) 2-4.

53 World Wide Fund for Nature and Allianz, above (n 12) 9. 
ethical investors seek reform through market pressure. Can the same occur for climate change?

\section{SRI AS A MEANS OF CLIMATE GOVERNANCE?}

\section{A. SRI Governance on Climate Change}

To what extent can SRI provide an effective means of governance, beyond official regulation, to facilitate action on climate change? Although once led by the churches and charitable foundations, could SRI become a means to articulate the climate concerns of a wider community of interests in a mass investor society?

The following discussion will examine several areas where the financial sector has pushed for action. These are: climate-related financial risk management, corporate reporting on GHG emissions and other climate-relevant information, and shareholder activism to exert change inside companies. However, before canvassing action in these domains, it is necessary to situate that analysis in the broader context of whether SRI can provide a surrogate form of regulation on social and environmental issues generally.

For several reasons, it is doubtful that SRI presently can significantly improve corporate behaviour on climate issues. First, the SRI movement has increasingly disavowed ethical arguments in favour of a business case for social investment. By tying social and environmental activism to furthering the 'bottom line', SRI has diminished its pretences to stand for change; there often remains a countervailing business case for financing socially irresponsible activities, or social and environmental values often cannot be factored into the cost-benefit calculations. Second, the niche SRI market hardly influences the financing costs of firms, and thereby cannot give climate-conscious companies a significant market advantage over their polluting rivals. Third, the SRI movement's own international codes of conduct, such as the UN Principles for Responsible Investment, offer relatively facile and discretionary standards that enable financial institutions merely to tinker with reform. The following sections of this article examine these three issues.

\section{B. The Triumph of Economic over Ethical Values}

SRI was once more commonly known as 'ethical investment'. It referred to investors who, for strictly ethical reasons, either sought to avoid profit from 'sinful' activities (a stance associated with deontological ethics) or who wished to use their financial resources to leverage positive change in the world (a teleological ethical position). ${ }^{54}$ Its apotheosis was the divestment movement,

54 N Carter and M Huby, 'Ecological Citizenship and Ethical Investment' (2005) 14 Environmental Politics 255; P Dembinski et al 'The Ethical Foundations of Responsible Investment' (2003) 48 Journal of Business Ethics 203. 
led by religious investors, against the apartheid regime in South Africa during the 1970s and 1980s. ${ }^{55}$ From about the late 1990s, SRI began to change its motivations and practices, as mainstream institutional investors such as large pension plans came under pressure to be more mindful of the social and environmental impacts associated with their financing. This pressure arose partly from non-governmental organisations (NGOs) which started to target not merely the front-line polluters, but also their financial backers. ${ }^{56}$ The shift in SRI was also influenced by precedent reforms to public development finance, such as the greening World Bank project financing during the 1980 s. $^{57}$

Yet, the mainstream financial community is generally not comfortable with SRI's traditional ethical agenda. ${ }^{58}$ Primarily, it believes that SRI may hurt financial returns, which could have adverse legal repercussions given that institutional investors owe fiduciary duties to their beneficiaries. There is some truth to this belief, although fiduciary duties give some latitude to invest responsibly, particularly where fund members demand ethical choices. ${ }^{59}$ Regardless, financial institutions have marshalled other arguments to avoid ethical investment. Investing on behalf of thousands or millions of investors, financial institutions fear immersion in acrimonious and irresolvable debates. about the correct ethical course. On the assumption that their fund members hold diverse ethical views on social and environmental issues, they conclude that it would be impossible to reach a consensus to guide investment policy. ${ }^{60}$ Alternatively, the maximization of financial returns is considered by fund managers as a clear and easily measurable benchmark to which they should be held to account.

Another factor undoubtedly shaping this shift in SRI philosophy is the 'ecological modernization' discourse, which became prevalent in Western environmental policy-making during the 1990s. It posits that economic development can be reconciled with environmental protection through technological innovation, managerial know-how, and the entrepreneurial spirit. ${ }^{61}$

55 Sparkes, above (n 19) 39.

$56 \mathrm{~S}$ Waygood, Capital Market Campaigning. The Impact of NGOs on Companies, Shareholder Value and Reputational Risk (Risk Books, London, 2006).

57 The Bank had incurred trenchant criticism for facilitating environmental degradation through project financing. O Perez 'The New Universe of Green Finance: From Self-Regulation to Multi-Polar Governance' in O Dilling, M Herberg, and G Winter (eds) Responsible Business: Self-Governance in Transnational Economic Transactions (Hart Publishing, Oxford, 2007) 151, 153 .

58 B J Richardson, 'Putting Ethics into Environmental Law: Fiduciary Duties for Ethical Investment' (2008) 46 Osgoode Hall Law Journal 243, 253.

59 As outlined in Freshfields Bruckhaus Deringer, A Legal Framework for the Integration of Environmental, Social and Governance Issues into Institutional Investment (UNEPFI, Geneva 2005).

$60 \mathrm{~J}$ Entine (ed), Pension Fund Politics: The Dangers of Social Investing (American Enterprise Institute, 2005).

${ }^{61} \mathrm{~S}$ Young, The Emergence of Ecological Modernisation: Integrating the Environment and the Economy? (Routledge, New York, 2001); M Andersen and I Massa, 'Ecological 
It optimistically projects that what is good for the environment is also good for business, based on the notion that cutting waste and using clean technologies improves market competitiveness and profitability. ${ }^{62}$ It thus discretely reframes the ethical and political dilemmas of industrialization as mere technical and managerial challenges. Such thinking has spilled into the SRI discourse, where corporate environmental performance is likewise increasingly evaluated in cost-benefit terms and improvements in such performance are seen as strengthening rather than diminishing investment returns. ${ }^{63}$

As a result of these beliefs and arguments, the SRI movement is now driven primarily by a business case. Corporate environmental performance is no longer commonly evaluated against uncompromising ethical standards such as the value of maintaining the integrity of the global climate. Rather, environmental problems such as rising sea level, increasing hurricanes, and other climate impacts are conceptualized as challenges of financial risk management. But only those risks that are deemed to be 'financially material'-ie posing tangible risks to investment assets or lucrative investment opportunities-receive attention. ${ }^{64}$ For example, the International Investors Group on Climate Change (IIGCC) proclaims its goal as to:

- Promote better understanding of the implications of climate change amongst our members and other institutional investors.

- Encourage companies and markets in which IIGCC members invest to address any material risks and opportunities to their businesses associated with climate change and a shift to a lower carbon economy. ${ }^{65}$

The SRI community downplays moral arguments. The United Nations Environment Program's Finance Initiative (UNEPFI), which is an industry partnership coordinated by the UN to promote SRI, explains in its report, Show Me the Money, that: '[t]he first-and arguably for investors the most important-reason to integrate [SRI] issues is, simply, to make more money'. ${ }^{66}$

Modernisation-Origins, Dilemmas and Future Directions' (2000) 2 Journal of Environmental Policy and Planning 337.

62 E Cohen-Rosenthal and J Musnikow (eds), Eco-Industrial Strategies: Unleashing Synergy between Economic Development and the Environment (Greenleaf Publishing, Sheffield, 2003).

${ }^{63}$ See research on this relationship: M Orlitzky, F Schmidt and S Rynes, 'Corporate Social and Financial Performance: A Meta-Analysis' (2003) 24 Organization Studies 403; M Yamashita, S Sen and M Roberts, 'The Rewards for Environmental Conscientiousness in the US Capital Markets' (1999) 12 Journal of Financial and Strategic Decisions 73; N Lorraine, D Collison and D Power, 'An Analysis of the Stock Market Impact of Environmental Performance Information' (2004) 28 Accounting Forum 7.

${ }^{64}$ UNEPFI, The Materiality of Social, Environmental and Corporate Governance Issues in Equity Pricing (UNEPFI, Geneva, 2004). ${ }_{65}$ See <http://www.iigcc.org > .

${ }_{66}$ UNEPFI, Show Me the Money: Linking Environmental, Social and Governance Issues to Company Value (UNEPFI, Geneva, 2006), 4. 
These attitudes can be contrasted with the ethical investor's position on climate change. The policy of the Interfaith Center for Corporate Responsibility's (ICCR) Global Warming Working Group is to:

- Encourage companies to report on their global warming emissions 'footprints', as well as disclose global warming related risks and opportunities to shareholders; and

- In recognition of future limits on global warming pollutants, encourage companies to behave proactively by reducing greenhouse gas emissions to sustainable levels. ${ }^{67}$

The ICCR, which coordinates SRI among religious investors, goes further than the IIGCC by stressing the priority of reducing carbon emissions. Its aim is to prevent or mitigate global warming for its own sake, rather than as a concern just tied to shareholder value.

The notion that environmental care and business success can be compatible is, of course, not inconceivable. The objection is that any such optimism can be a pretext for the perpetuation of business-as-usual. A huge gap between SRI based on the yardstick of financial materiality and an ecologically sustainable economy persists. Investment analysts often perceive social or environmental values as too nebulous for workable financial quantification. ${ }^{68}$ Values such as biodiversity or climate integrity cannot be captured by conventional financial accounting systems unless they give rise to specific expenses and income attributable to an individual organization. ${ }^{69}$ Further, a countervailing business case for environmentally problematic activities often exists. The continuing investment in Canada's oil sands is one controversial example. ${ }^{70}$ Without additional ethical motivations, financiers may lack the incentive to take actions beyond those prescribed by a business case.

\section{SRI's Stunted Market Influence}

The SRI sector remains small and appears unable to influence significantly the environmental behaviour of companies. SRI is essentially a boutique niche, likely holding less than ten per cent of the capital markets of the major Western economies. ${ }^{71}$ Much of the industry-generated research appears to exaggerate

${ }^{67}$ See <http://www.iccr.org/issues/globalwarm/goalsobjectives.php >.

${ }^{68} \mathrm{~S}$ McGeachie, M Kiernan and E Kirzner, Finance and the Environment in North America: The State of Play of the Integration of Environmental Issues into Financial Research (Canadian Department of the Environment, Ottawa 2005) 57.

${ }^{69} \mathrm{~S}$ Goodman and T Little, The Gap in GAAP: An Examination of Environmental Accounting Loopholes (2003).

${ }^{70}$ K Makin, 'High-stakes Battle Looms over Oil-Sands Pollution' Globe and Mail (15 August 2007) A1.

${ }_{11}$ Social Investment Forum (SIF), 2007 Report on Socially Responsible Investing Trends in the United States (SIF, 2008); European Social Investment Forum (Eurosif), Socially Responsible Investment among European Institutional Investors (Eurosif, Paris, 2006). 
the extent of the SRI market, because the peak SRI associations are reluctant to define clearly what should qualify as 'socially responsible'. A fund for example that merely screens against tobacco stocks, but otherwise holds a conventional investment portfolio, is sometimes counted as SRI. ${ }^{72}$ Despite its increasing pragmatic business stance, the SRI market remains small because many mainstream financial institutions have yet to appreciate the business risks of environmentally irresponsible behaviour, or they even see financial advantages in funding such behaviour. Even if the SRI market were significantly larger, it is doubtful whether that alone would commensurately boost its influence without other reforms.

Advocates of SRI believe that it financially rewards ethical firms through additional investment and punishes unethical ones by divestment. It thereby should both enhance returns for social investors while give firms incentives to improve their environmental and social behaviour. ${ }^{73}$ Certainly, 'SRI is more likely to be relevant whenever companies are heavily dependent on the stock market as a financing instrument'. ${ }^{74}$ Corporate financing data suggests that most companies, especially mature firms, can self-finance their operations and growth through surplus revenue. ${ }^{75}$ Yet, even they do not remain entirely insulated from the demands of investors. ${ }^{76}$ A declining stock price can affect a firm's market capitalization and thus its stock market listing. Further, the remuneration of corporate management is often tied to stock options, giving managers incentives to adopt measures to keep stock prices artificially high.

However, theories of corporate finance doubt that stock market trading can achieve the effects predicted by proponents of SRI ${ }^{77}$ Conventional finance theory suggests that investors can trade any quantity of a firm's shares without affecting its price. This is because in an efficient equity market where demand for a company's stock is almost perfectly elastic, ${ }^{78}$ the price of a stock simply reflects the expected future cash flows, and all informed investors supposedly

72 Social Investment Forum (SIF), 2005 Report on Socially Responsible Investing Trends in the United States: A 10-Year Review (SIF, Washington DC, 2006) 9.

${ }^{73}$ P Camejo, The SRI Advantage: Why Socially Responsible Investing has Outperformed Financially (New Society Publishers, Gabriola Island, 2002); R Sparkes and C Cowton, 'The Maturing of Socially Responsible Investment: A Review of the Developing Link with Corporate Social Responsibility' (2004) 52 Journal of Business Ethics 45.

74 A Beltratti, Socially Responsible Investment in General Equilibrium (Università Bocconi, Milan, 2003) 21.

$75 \mathrm{~J}$ Corbett and T Jenkinson, 'The Financing of Industry, 1970-1989: An International Comparison' (1996) 10 Journal of the Japanese and International Economies 71; but compare to A Hackethal and R Schmidt, Financing Patterns: Measurement Concepts and Empirical Results, Working Paper (University of Frankfurt, 2003).

${ }^{76} \mathrm{M}$ Jensen and K Murphy, 'CEO Incentives-It's Not How Much You Pay, But How' (1990) 68(3) Harvard Business Review 138.

77 J Langbein and R Posner, 'Social Investing and the Law of Trusts' (1980) 79 Michigan Law Review $72 \mathrm{M}$ Knoll, 'Ethical Screening in Modern Financial Markets: The Conflicting Claims Underlying Socially Responsible Investment' (2002) 57 Business Lawyer 681.

${ }^{78} \mathrm{C}$ Loderer et al, 'The Price Elasticity of Demand for Common Stock' (1991) 46 Journal of Finance 621 . 
value the company's stock identically. ${ }^{79}$ Any SRI-motivated divestment should not per se change the expected cash flow from the targeted firm's activities, and therefore its stock prices should not change. ${ }^{80}$ Of course, the stock price should vary if potential traders believe pressure on the stock reflects a downward or upward view of the company's underlying financial prospects. Business case SRI that educates the market to the financial consequences of firms' environmental behaviour may have such an effect. It is when social investors view unethical behaviour differently from the market as a whole that they may be marginalized. Other theoretical research, which assumes that markets do not always behave according to textbook theory, suggests that SRI can alter the cost of capital when the stock of a firm is risky, unique, or the stock trades in small, restrictive markets. ${ }^{81}$ Otherwise, some theoretical models predict that social investors would need to hold at least 20 per cent of the market, but likely much more, to affect stock prices. ${ }^{82}$

Actual evidence of SRI's influence generally supports the foregoing assessments. The most comprehensive studied action is the South African boycott, which appears to have had modest effect on the targeted companies. ${ }^{83}$ The widespread divestment from the tobacco industry appears to have had minimal impact on their stock prices. ${ }^{84}$ Some research suggests a short-term impact on the stock prices of companies tainted by an environmental scandal or pollution fines, but this is because such news is perceived by the market to have implications for the profitability of the affected firm. ${ }^{85}$

79 G Arnold, Handbook of Corporate Finance (Financial Times and Prentice Hall, 2005) $314,330$.

${ }^{80} \mathrm{~W}$ Davidson, D Worell and A El-Jelly, 'Influencing Managers to Change Unpopular Corporate Behavior through Boycotts and Divestitures' (1995) 34 Business and Society 171.

${ }^{81}$ P Rivoli, 'Making a Difference or Making a Statement? Finance Research and Socially Responsible Investment' (2003) 13 Business Ethics Quarterly 271.

${ }^{82} \mathrm{R}$ Heinkel, A Kraus and J Zechner, 'The Effect of Green Investment on Corporate Behavior' (2001)36 Journal of Financial and Quantitative Analysis 431; J Angel and P Rivoli, 'Does Ethical Investing Impose a Cost Upon the Firm? A Theoretical Perspective' (1997) 6(4) Journal of Investing 57. This discussion, concerning equity investment, is not necessarily applicable to bank lending. Banks can have relatively more influence over borrowers, especially small enterprises with few financing options, and firms in large project financing deals seeking huge loans: Jeucken, above; P Thompson, 'Bank Lending and the Environment: Policies and Opportunities' (1998) 16(6) International Journal of Bank Marketing 243.

${ }^{83}$ S Teoh, I Welch and P Wazzan, 'The Effect of Socially Activist Investment Policies on the Financial Markets: Evidence from the South African Boycott' (1999) 72 Journal of Business 35; but compare to R Kumar, W Lamb and R Wokutch, 'The End of South African Sanctions, Institutional Ownership, and the Stock Price of Boycotted Firms' (2002) 41 Business and Society 133.

84 T Burroughes, 'Ethical Investors Losing Out as Tobacco Stocks Burn Up Britain's Equity Markets' The Business (24 February 2007).

${ }_{85}$ Lorraine, Collison and Power, above (n 63); D Cormier, M Magnan and B Morard 'The Impact of Corporate Pollution on Market Valuation: Some Empirical Evidence' (1993) 8 Ecological Economics 135; J Hamilton 'Pollution as News: Media and Stock Market Reactions to the Toxics Release Inventory Data' (1995) 28 Journal of Environmental Economics and Management 98. 
SRI may also achieve some influence when undertaken through shareholder advocacy and engagement with corporate management. Institutional investors have traditionally been passive investors, lacking incentives to monitor companies because of the costs involved and difficulties of coordinating action. ${ }^{86}$ While some commentators believe they increasingly are more active, ${ }^{87}$ the impact of such activism appears episodic and fleeting. SRI-inspired shareholder resolutions rarely garner more than ten per cent of the votes at a meeting. ${ }^{88}$ However, sometimes defeated shareholder resolutions may induce management to work cooperatively, as they may interpret even modest dissent as reflective of broader unease about company policies.

In sum, SRI has yet to transform financial markets and the companies they finance. It has generally not yet had the strength of a surrogate regulator, able to influence companies through reward or divestment to improve their behaviour. Indeed, SRI appears to rely on the underlying system of environmental regulation to alter the financial advantages between polluters and socially responsible firms. Regulatory and public policy reforms are therefore probably essential if SRI is to be a means of advancing action on climate change and other environmental problems. But rather than continue to target only the 'front-line' companies, legal reform should also directly challenge the behaviour of their financial sponsors. Such reforms could include redefining the fiduciary duties of investment institutions to strengthen the mandate for SRI, improving the reporting by companies and their financiers on their social and environmental performance, integrating social accounting standards, and in some cases imposing environmental liability on financial sponsors. ${ }^{89}$ The SRI movement, however, has not greatly clamoured for such reforms; it has preferred to draft its own codes of conduct for financiers to adopt voluntarily, as the following section canvasses.

\section{SRI Codes and Standards}

\section{Codes related to climate finance}

The SRI sector is more than a just a certain style of financing. It has also fashioned its own codes of conduct to help coordinate, standardize, and facilitate responsible financing. These voluntary mechanisms, developed by market and civil society institutions, have proliferated since $2000 .^{90}$

This web of SRI governance relies on a diversity of methods, structures and objectives, broadly classifiable into four types (although any individual

\footnotetext{
$86 \mathrm{~J}$ Parkinson, Corporate Power and Responsibility: Issues in the Theory of Company Law (Clarendon Press, Oxford, 1995) 168-69.

${ }^{87}$ Davis, Lukomnik and Pitt-Watson, above (n 21) 15-16.

88 ibid 16-18.

89 B J Richardson, 'Diffusing Environmental Regulation through the Financial Services Sector: Reforms in the EU and other Jurisdictions' (2003) 10(3) Maastricht Journal of European and Comparative Law 1.

90 Perez, above (n 57).
} 
instrument may contain several of these features). First, there are normative frameworks that set substantive performance standards for social and environmental conduct. An example is the Collevecchio Declaration on Financial Institutions. ${ }^{91}$ Process standards, enabling the assessment, verification, and communication of performance, constitute another form of governance. They include the Equator Principles ${ }^{92}$ and the Global Reporting Initiative. ${ }^{93}$ Third, management systems, such as the International Organization for Standardization's ISO 14001 regime, create a structure to guide the management of environmental and social activities and impacts. ${ }^{94}$ Finally, comparative evaluation mechanisms have been developed by the SRI industry to evaluate and rank corporate performance for the purpose of selecting investments. These rating mechanisms include SRI stock market indexes such as the Dow Jones Sustainability Indexes ${ }^{95}$ and the FTSE4 Good Index Series. ${ }^{96}$

In these respects, the SRI industry mirrors the general drift to corporate self-regulation in most Western economies. The trend has been extensively analysed in the literature, which need not be repeated here. ${ }^{97}$ Many commentators and policy-makers are sceptical of corporate intentions, and doubt that voluntary mechanisms provide a credible means of environmental regulation. ${ }^{98}$ Many of the SRI codes are too ambiguous and open-ended in their expectations. The most demanding standards are contained in the Collevecchio Declaration, a product of civil society institutions, which has been largely ignored by mainstream investors. They favour more discretionary and procedural-based standards, dealing with disclosure, reporting, and auditing of investment activities. While some reflexive law scholarship is confident that such measures can induce positive changes in affected organizations' behaviour, ${ }^{99}$ by encouraging reflection and learning, the empirical evidence is inconclusive. ${ }^{100}$ Voluntary mechanisms also typically lack

${ }_{91}$ See $<$ http://www.foe.org/camps/intl/declaration.html $>$.

${ }_{92}$ See $<$ http://www.equator-principles.com/index.shtml $>$.

93 See < http://www.globalreporting.org $>$.

94 See generally Ruth Hillary (ed), ISO 14001: Case Studies and Practical Experience (Greenleaf Publishing, Sheffield, 2000).

95 See $<$ http://www.sustainability-index.com $>$.

${ }_{96}$ See <http://www.ftse.com/Indices/FTSE4Good_Index_Series/index.jsp >.

${ }^{97}$ See eg S Wood, 'Voluntary Environmental Codes and Sustainability' in B J Richardson and S Wood (eds), Environmental Law for Sustainability (Hart Publishing, Oxford, 2006) 229; R Gibson (ed), Voluntary Initiatives: The New Politics of Corporate Greening (Broadview Press, Peterborough, 1999); J Moon, 'The Firm as Citizen? Social Responsibility of Business in Australia' (1995) 30(1) Australian Journal of Political Science 1.

98 eg Ian Maitland, 'The Limits of Business Self-Regulation' (1995) California Management Review (1995) 27(3) 132; Wood, above (n 97).

99 See Teubner, Farmer and Murphy, above (n 31).

100 eg M Vidovic and N Khanna, 'Can Voluntary Pollution Prevention Programs Fulfill Their Promises? Further Evidence from the EPA's 33/50 Program' (2007) 53 Journal of Environmental Economics and Management 180; US Government Accountability Office (GAO), Climate Change: EPA and DOE Should Do More to Encourage Progress Under Two Voluntary Programs (GAO, Washington DC, 2006); C Woolfson and M Beck (eds), Corporate Social Responsibility Failures in the Oil Industry (Baywood Publishing, Amityville, 2005). 
credible sanctions or enforcement mechanisms, so that compliance has come to depend on peer pressure, the discipline of the market, or sustained NGO demands. The corporate stone-walling of the draft UN Norms on the Responsibilities of Transnational Corporations illustrates corporate attitudes to regulatory standards with teeth. ${ }^{101}$

A few voluntary codes have been drafted to address climate finance specifically. The Climate Principles is one example of a voluntary initiative that purports to provide a 'common global standard of best practice not only to assist the finance sector in managing its own climate impact but also to assist the sector in supporting its clients and stakeholders in managing their own impacts' ${ }^{102}$ The Principles were finalized in December 2008 by the Climate Group, an NGO, in dialogue with some 20 financial institutions. The Climate Principles address most aspects of the financial industry including investment management, retail banking, insurance, and project finance. For example, in relation to the financing of projects that involve the release of at least 100,000 tons of carbon dioxide equivalent annually, signatories to the Principles are expected to request that their clients 'quantify and disclose' GHG emissions associated with the project, to 'monitor and report GHG emissions annually in accordance with internationally-recognized methodologies' and to 'evaluate technically and financially feasible options to reduce or offset project-related GHG emissions'. ${ }^{103}$ The Climate Principles build on the 'Carbon Principles', adopted in February 2008 by six US banks, 'to provide a consistent approach for banks and their US power clients to evaluate and address carbon risks in the financing of electric power projects' ${ }^{104}$ Like the Climate Principles, the Carbon Principles emphasize procedural standards rather than absolute prohibitions on the financing of fossil fuel-intensive developments or companies, thereby providing latitude for business-as-usual. But far more influential and widely endorsed than either of these two codes is the UNPRI, as the next section explains.

\section{UN Principles for Responsible Investment (UNPRI)}

Designed primarily for institutional investors, the UNPRI is a voluntary code of conduct that combines process and substantive performance standards. It was developed under the auspices of UNEPFI, which established a working group comprised of invited investment professionals, who were supported by

101 UN Economic and Social Council (ECOSOC), Sub-Commission on Promotion and Protection of Human Rights, Norms on the Responsibilities of Transnational Corporations and Other Business Enterprises with Regard to Human Rights (UN ECOSOC, New York, 2003).

${ }_{102}$ Climate Group: <http://www.theclimategroup.org/about/corporate_leadership/climate_ principles $>$.

${ }_{103}$ Article 2.7, at $<$ http://www.theclimategroup.org/assets/resources/TCP_English.pdf $>$.

104 See <http://carbonprinciples.org/ $>$. 
a multi-stakeholder collection of some 70 experts including representatives from some major environmental NGOs.

The UNPRI is a succinct code of six core principles, each of which is illustrated by several 'possible actions'. The principles state:

1. We will incorporate environmental, social and corporate governance (ESG) issues into investment analysis and decision-making processes.

2. We will be active owners and incorporate ESG issues into our ownership policies and practices.

3. We will seek appropriate disclosure on ESG issues by the entities in which we invest.

4. We will promote acceptance and implementation of the Principles within the investment industry.

5. We will work together to enhance our effectiveness in implementing the Principles.

6. We will each report on our activities and progress towards implementing the Principles. ${ }^{105}$

The accompanying list of possible actions provides a best practice guide. Concerning the second principle, for instance, the suggested actions to achieve active ownership include to 'exercise voting rights', 'develop an engagement capability', and 'file shareholder resolutions consistent with long-term ESG considerations'. Through such actions, the UNPRI secretariat sees several benefits:

Implementing the Principles will lead to a more complete understanding of a range of material issues, and this should ultimately result in increased returns and lower risk. There is increasing evidence that ESG issues can be material to performance of portfolios, particularly over the long term.

PRI signatories are also part of a network, with opportunities to pool resources and influence, lowering the costs and increasing the effectiveness of research and active ownership practices. The Initiative also supports investors in working together to address systemic problems that, if remedied, may then lead to more stable, accountable and profitable market conditions overall. ${ }^{106}$

In addition to the narrowness of this business case orientation, the UNPRI has some specific limitations. Among the list of conceivable actions for the first principle, there is no stated expectation that investors actually incorporate social or environmental factors into their ultimate portfolio choices. The Principles do not require a signatory to demonstrate any particular performance standards with regard to human rights or environmental protection. The second principle on active ownership focuses on participation in investee companies, while curiously ignoring the equally pressing need to democratise

105 See $<$ http://www.unpri.org/principles $>$.

106 UNPRI, 'Frequently Asked Questions': < http://www.unpri.org/faqs >. 
decision-making within financial institutions. Nor do the UNPRI insist on any independent audit or verification mechanism to assess the quality of signatories' implementation. To reassure investors, the UNPRI explains:

There are no legal or regulatory sanctions associated with the Principles. They are designed to be voluntary and aspirational. There may be reputational risks associated with signing up and then failing to take any action at all, but the commitments are, for most signatories, a work in progress and a direction to head in rather than a prescriptive checklist with which to comply. ${ }^{107}$

Such an insouciant attitude contrasts with the rigour of the Collevecchio Declaration, developed by NGOs. Its ambitious 'commitment to sustainability' principle obliges investors to:

expand their missions from ones that prioritize profit maximization to a vision of social and environmental sustainability. A commitment to sustainability would require financial institutions to fully integrate the consideration of ecological limits, social equity and economic justice into corporate strategies and core business areas (including credit, investing, underwriting, advising), to put sustainability objectives on an equal footing to shareholder maximization and client satisfaction, and to actively strive to finance transactions that promote sustainability.

Such a standard, if adopted widely by financial institutions, would provide a strong platform to address climate change as a valuable goal in its own right.

Nonetheless, accommodating rather than radically challenging the financial sector, the UNPRI will likely remain one of the main benchmarks for SRI. As of June 2008, over 350 institutions had signed the Principles, holding more than US\$14 trillion in assets. ${ }^{108}$ The UNPRI has been generally well received by the finance sector, it being attracted to the Principles for the eminence of their sponsorship by the UN while still maintaining considerable latitude in the open-ended standards.

While the UNPRI does not explicitly refer to climate change, conceivably it is the type of environmental issue that signatories to the Principles should address. Unlike the UNEPFI, the UNPRI secretariat has not established any dedicated working groups or major projects that focus on global warming and SRI. ${ }^{109}$ Some individual signatories mention how they use the UNPRI to inform their policies. AMP Capital states that it 'is progressively applying the UNPRI to our investment activities across all asset classes ... on the potential risks and issues around policy response to climate change'. ${ }^{110}$ However, most financiers ostensibly interested in SRI typically are signatories to several

107 ibid.

108 UNPRI Secretariat, PRI Report on Progress 2008 (UNPRI, London, June 2008), 2.

109 UNEPFI has a Climate Change Work Stream: < http:www.unepfi.org/work_streams/ climate_change/index.html >

110 AMP Capital, 'AMP Capital a signatory to the United Nations Principles of Responsible Investment', <http://www.ampcapital.com.au/corporatecentre/unpri.asp > . 
codes and regimes, and do not purport to attribute actions on climate change or other environmental issues to any one standard such as the UNPRI.

The following section reviews some of the specific ways that institutional investors are addressing climate change issues pursuant to the UNPRI and other evolving SRI standards.

\section{INVESTOR RESPONSES TO CLIMATE CHANGE}

\section{A. Risk Management}

Improved understanding and management of the financial risks posed by climate change has been the primary concern of the SRI community. With their diverse portfolios and long-term financial liabilities, all institutional investors have good reasons to be attentive to climate-related risks. They have established some collaborative forums to share ideas and best practices. One example is the Investor Network on Climate Risk (INCR), which was created out of the UN-convened Investor Summit on Climate Risk in 2003. ${ }^{11}$ As of January 2009, the INCR claimed a membership of approximately 75 institutional investors. It organizes conferences to educate fund managers about climate risks, and publishes various reports. Another association performing a similar collaborative role is the UK-based Institutional Investors' Group on Climate Change (IIGCC), with some 50 members as of January 2009. ${ }^{112}$ The UN is also partnering with institutional investors through the UNEPFI's Climate Change Work Stream. It seeks to raise awareness of climate issues in the financial sector and has been a rare advocate for public policy reform. ${ }^{113}$

Some individual financial institutions are also voicing concerns and taking action. In 2001, the UK's Universities Superannuation Scheme published a working paper examining climate change as a financial risk. ${ }^{114}$ In the US, public sector pension funds have also taken the lead in identifying climate change as a long-term risk to portfolio companies." The "Green Wave Initiative', launched in 2004 by the California State Treasurer with the state's two largest public sector funds, ${ }^{116}$ commits the participants to invest millions in climate-friendly technologies and clean energy companies. ${ }^{117}$

For banks, climate change can pose project specific risks, such as to investments located in low-lying coastal areas or projects dependent on

\footnotetext{
111 See <http:/www.incr.com $>$.

112 See < http://www.iigcc.org >. 113 See <http://unepfi.net/cc $>$.

114 M Mansley and A Dlugoleck, Climate Change-A Risk Management Challenge for Institutional Investors (Universities Superannuation Scheme, London 2001).

${ }^{115} \mathrm{C}$ Williams and J Conley, 'An Emerging Third Way? The Erosion of the Anglo-American Shareholder Value Construct' (2005) 18 Comell International Law Journal 555.

${ }_{116}$ California Public Employees' Retirement System (CalPERS) and the California State Teachers' Retirement System (CalSTRS).

117 J Sandred, 'Catching the Green Wave: Investment in Environmental Technology Gaining Momentum', San Francisco Chronicle (31 May 2004).
} 
predictable weather patterns. ${ }^{118}$ As Philpott explains, 'there is not, at present, a standard approach within the international banking industry for transparency and accountability for the global warming performance of project finance'. 119 A few banks are committing themselves to absolute reductions in GHG emissions in their lending portfolio. In its energy-lending portfolio, the Bank of America promises to reduce the emissions of projects it finances by seven per cent. ${ }^{120}$ The HSBC unveiled its carbon management plan in December 2004, committing the bank to 'carbon neutrality' from its operations globally. ${ }^{121}$ Both the Bank of America and HSBC are signatories of the Carbon Principles and Climate Principles respectively.

Climate risks have become an even greater concern in the property and casualty insurance industry. ${ }^{122}$ Costly weather catastrophes that spiked during the 1980 s and 1990 s - seen as a harbinger of global warming - pushed the insurance industry into the climate policy debates. ${ }^{123}$ Some insurance companies responded by withdrawing coverage for certain risks, hiking premiums, imposing greater deductibles, and adopting physical risk management and other protective measures as a precondition to insurance. ${ }^{124}$ Some also exerted pressure on policy-makers, lobbying for regulatory action, and collaborating with public authorities on research and preventative measures. ${ }^{125}$ Yet, curiously, some insurance companies appear to have often disregarded the climate risks in their own investment portfolios. ${ }^{126}$

Insurance cannot eliminate the risks of global warming occurring, although it may indirectly help to reduce the ensuing damage by encouraging adoption of mitigation measures, and by channelling compensation to victims of the effects of climate change. Insurers have also pioneered new catastrophe risk mechanisms, such as catastrophe future and weather derivatives, to tap into

118 J Philpott, 'Keeping it Private, Going Public: Assessing, Monitoring, and Disclosing the Global Warming Performance of Project Finance' (2005) 5 Sustainable Development Law and Policy 45. 119 ibid 47.

${ }^{120}$ Bank of America, 'Bank of America Climate Change Position', at <http://www. bankofamerica.com/environment $>$. Yet, as recently as June 2007, the Bank of America was the target of protest actions for its continuing investments in the coal industry: 'Activists Drape $50 \mathrm{ft}$ Banner Across From B of A Headquarters, Call on Bank to Stop Funding Dirty Coal'Asheville Indymedia (23 October 2007).

121 'HSBC Earns Credit for Being First 'Carbon Neutral' Bank' GreenBiz.com (7 December 2004).

${ }^{122}$ Innovest, Climate Change and the Financial Services Industry. Module 1-Threats and Opportunities (UNEPFI Climate Change Working Group, Geneva, 2002) 16-17.

${ }_{23}$ C Flavin, 'Storm Warnings: Climate Change Hits the Insurance Industry' (1994) 7 World Watch 10 .

124 A Dlugolecki, 'An Insurer's Perspective' in Jeremy Leggett (ed) Climate Change and the Financial Sector (Gerling Akademie-Verlag, Munich, 1996) 64, 75.

125 D Kirk, 'Insurers Voice Need to Combat Climate Risks' (1999) 33(45) Business Insurance 45; F Nutter, 'Global Climate Change: Why US Insurers Care' (1999) 42(1) Climatic Change 45.

126 FM Research, Capital Punishment: UK Insurance Companies and the Global Environment (Friends of the Earth, London, 2000) 47-49. 
the deep resources of the capital markets. ${ }^{127}$ The market for weather derivatives contracts allows climate-related risks to be hedged. ${ }^{128}$ To illustrate, if a disaster occurs, the insurer that issued the catastrophe bond would pay claims with the funds that would otherwise have gone to the bondholders. If good weather prevails during the bond period (typically a year), investors gain by the return of their principal plus interest payments. ${ }^{129}$

\section{B. Disclosing Investment-Related Climate Impacts}

Socially responsible investors need to know about companies' GHG emissions if they are to construct environmentally responsible and less risky investment portfolios. The lack of well established legal obligations to report such information, coupled with the lack of comprehensive, standardised methods for reporting such emissions on a voluntary basis, has hindered SRI on climate issues. ${ }^{130}$ Further, companies facing material climate-related financial risks are disinclined to disclose fully such information. ${ }^{131}$ In some jurisdictions such as Canada, the UK, and the US, general corporate financial reporting laws require companies to disclose any costs or benefits associated with their environmental performance that may materially affect the firm's financial health. ${ }^{132}$ Generally poor implementation of such standards has encouraged the SRI industry to develop its own reporting protocols.

In addition to petitioning securities regulators to improve their enforcement of disclosure rules, ${ }^{133}$ financial institutions have designed their own informational tools to enable action on global warming. Among these tools are the Carbon Disclosure Project (CDP) and the Greenhouse Gas Protocol Initiative (GHGPI). They generate data that help facilitate dialogue between financial institutions and firms on climate change.

127 See further D Jaffee and T Russell, 'Catastrophe Insurance: Capital Markets and Uninsurable Risks' (1997) 64 Journal of Risk and Insurance 205; S D'Arcy and V France 'Catastrophe Futures: A Better Hedge for Insurers' (1992) 59 Joumal of Risk and Insurance 575.

128 See G Chichilnisky and G Heal, 'Managing Unknown Risks' (1998) 24(4) Journal of Portfolio Management 85.

129 See J Tynes, 'Catastrophe Risk Securitization' (2000) 19(1) Journal of Insurance Regulation 3.

${ }_{130}$ PricewaterhouseCoopers (PWC) and International Emissions Trading Association (IETA), Uncertainty in Accounting for the EU Emissions Trading Scheme and Certified Emission Reductions (PWC and IETA, London, 2007) 15-16.

131 Economist Intelligence Unit, A Change in the Climate. Is Business Going Green? (UK Trade and Investment, London, 2007) 8.

${ }^{132}$ eg Canadian Institute of Chartered Accounts (CICA), MD\&A Disclosure about the Financial Impact of Climate Change and Other Environmental Issues: Discussion Brief (CICA, 2005); J Smith, 'The Implications of the Kyoto Protocol and the Global Warming Debate for Business Transactions' (2005) 1 New York University Journal of Law and Business 511, 529; M Chan-Fishel, Fifth Survey of Climate Change Disclosure in SEC Filings of Automobile, Insurance, Oil and Gas, Petrochemical, and Utilities Companies (Friends of the Earth, San Francisco, 2006)

${ }^{133} \mathrm{~S}$ Mufson, 'SEC Pressed to Require Climate-Risk Disclosures' Washington Post (18 September 2007) D01. 
The CDP is a mechanism that coordinates requests from institutional investors for information on companies' climate change-related activities. ${ }^{134}$ Begun in December 2000, the CDP allows investors to collectively endorse a single global request for disclosure of information regarding companies' GHG emissions, vulnerability to climate change impacts, emission trading activities and their policies on climate change. These requests are made annually to an ever-larger pool of major companies. By mid-2008, over 3,000 corporations were asked to report to the CDP, on behalf of nearly 400 investment institutions. ${ }^{135}$ About half responded. Since 2007, the CDP has also asked for information about companies' emissions connected to their supply chains, thereby helping to provide a more comprehensive picture of GHG pollution. ${ }^{136}$ The CDP is now probably the largest registry of corporate GHG emissions data in the world, for the benefit of hundreds of climateconscious institutional investors.

Whereas the CDP focuses on reporting data, the GHGPI aims to improve the underlying methods of accounting behind such data. ${ }^{137}$ Developed by the World Business Council for Sustainable Development and the World Resources Institute, the GHGPI consists of two modules. The Corporate Accounting and Reporting Standard Module can assist companies and other organisations to identify, calculate, and report GHG emissions. This module is limited in that it does not adequately address the position of financial institutions, which do not have to account for the GHG emissions of companies they fund (the latter are deemed the responsible entities). The second module is the Project Accounting Protocol and Guidelines, designed for calculating reductions in GHG emissions from specific projects and land use changes. The GHGPI provides the accounting framework for the European Union's Emissions Trading Scheme and other initiatives.

Both the CDP and GHGPI inform some other disclosure regimes. One is the World Economic Forum's Global Greenhouse Gas Register (GHG Register), established in 2004, to provide a global inventory of corporate emissions inventories and reduction targets, based on the GHGPI. ${ }^{138}$ The Global Reporting Initiative, to some the gold standard for sustainability reporting, contains directions on reporting relevant information regarding climate change. ${ }^{139}$ The Global Reporting Initiative's G3 Reporting Framework of October 2006 introduced a specific reporting indicator on the 'financial implications due to climate change'. ${ }^{140}$ Another initiative also informed by the GHGPI is the ISO

134 See <http://www.cdproject.net $>$.

135 See <http://www.cdproject.net/faqs.asp >.

136 Remarks by Paul Dickinson, Chief Executive Officer, CDP (UNEPFI Global Roundtable, Melbourne, Australia, 24-25 October 2007).

${ }^{137}$ See <http://www.ghgprotocol.org $>$.

${ }_{138} \mathrm{See}<\mathrm{http}: / /$ www.weforum.org/en/initiatives/ghg/GreenhouseGasRegister $>$.

139 See <http://www.globalreporting.org $>$.

$140 \mathrm{See}<\mathrm{http}: / / \mathrm{w} w w$.globalreporting.org/ReportingFramework/G3Online $>$. 
14064 standard, released in March 2006. It aims to promote consistency, transparency, and credibility in GHG emission quantification, reporting, and verification, to thereby facilitate trade in GHG allowances and credits. ${ }^{141}$ The ISO 14064 is complemented by ISO 14065, with requirements to accredit or recognise bodies that undertake GHG validation or verification. ${ }^{142}$

Overall, these reporting mechanisms are perhaps the most promising achievement of the financial sector on climate change issues. They provide a rare example of where SRI can provide leadership on governance of climate issues, setting an example for governments to follow. These successes probably owe to the fact that they do not actually require any changes in the behaviour of financial institutions themselves-only of the companies they fund.

\section{Shareholder Activism}

Another way that the financial sector may voice its concerns about climate change is through shareholder activism. Financiers sometimes use shareholder resolutions and dialogue to spur corporate management to meet their demands on matters ranging from corporate governance to environmental practices. Shareholder resolutions on climate issues typically ask management to report on climate change risks that may affect the firm, rather than ask the firm to adopt specific actions to mitigate their emissions, which, in some jurisdictions, could be construed as an impermissible attempt to dictate managerial action. While many corporations strenuously resist such 'interferences', some react positively; they may agree to disclose their GHG emissions, to set emission reduction goals, make energy efficiency investments, and integrate climate risks into core business plans.

Nonetheless, shareholder resolutions on climate issues are rare and have garnered little open support until recently. ${ }^{143}$ Most such resolutions have been filed in the US. A study of such proposals filed in 81 US companies during the period 2000-2003 found that they only attracted on average support from 13 per cent of the shareholders. ${ }^{144} \mathrm{~A}$ survey by the Social Investment Forum documented 25 shareholder resolutions on climate issues in 2003 , rising to

141 It comprises three specific standards: ISO 14064-1: 2006, Greenhouse Gases-Part 1: Specification with Guidance at the Organization Level for the Quantification and Reporting of Greenhouse Gas Emissions and Removals; ISO 14064-2: 2006, Greenhouse Gases-Part 2: Specification with Guidance at the Project Level for the Quantification, Monitoring And Reporting of Greenhouse Gas Emission Reductions and Removal Enhancements; ISO 14064-3: 2006, Greenhouse Gases-Part 3: Specification with Guidance for the Validation and Verification of Greenhouse Gas Assertions.

142 ISO 14065: 2007, Greenhouse Gases-Requirements for Greenhouse Gas Validation and Verification Bodies for Use in Accreditation or Other Forms of Recognition.

${ }^{143}$ R Monks et al, 'Shareholder Activism on Environmental Issues: A Study of Proposals at Large US Corporations (2000-2003)' (2004) 28 Natural Resources Forum 317, 319.

144 ibid 321. 
35 in 2005. The resolutions attracted an average of 16.7 per cent support in 2003 , which declined to 10.8 per cent in $2005 .{ }^{145}$ One resolution asking the ExxonMobil board of directors comprehensively to review how it would meet GHG reduction targets in countries subject to the Kyoto Protocol received a relatively high 28.3 per cent of the votes. ${ }^{146}$ The 2008 proxy season in the US saw a further spike in climate change-related resolutions, with 57 proposals filed in American companies. ${ }^{147}$ Shareholder resolutions that went to a vote garnered a record high average voting support of 21.6 per cent, including nearly 40 per cent backing for a resolution filed with Allegheny Energy, the most ever for a global warming resolution in the US. ${ }^{148}$ However, such resolutions remain rare in other jurisdictions, such as in the UK where investors often prefer informal dialogue with corporate management. ${ }^{149}$

Shareholder activism on climate change is usually sponsored by a limited range of financial institutions. Public sector pension funds and faith-based investors are the most climate-conscious shareholders. ${ }^{150}$ Mutual funds have been the most taciturn, although some commentators believe this will change in the US and Canada in the wake of securities regulation reforms in 2003 and 2005 respectively requiring such funds in these jurisdictions to disclose their proxy voting records. ${ }^{151}$ Until now, the US mutual fund industry has tended to routinely side with management on shareholder resolutions. One report analyzed how the US's 100 largest mutual funds voted their shareholder proxies on climate change resolutions filed in $2005 .{ }^{152}$ During that period, only three investment companies (Columbia, Franklin Templeton, and Neuberger Berman) had proxy voting guidelines allowing fund manages to support proposals for corporate disclosure on environmental issues such as climate change. Moreover, of votes actually cast, no mutual funds surveyed supported any climate change proposals filed. For example, Excelsior Funds' Voting Guidelines on Social and Environmental Issues (adopted in October 2004) state:

We do not believe that social and political restrictions should be placed on a company's business operations, unless determined as appropriate by

${ }^{145}$ Social Investment Forum (SIF), 2005 Socially Responsible Investing Trends in the United States: 10-Year Review (SIF, Washington DC, 2006) 19 (in each year, some of the resolutions were withdrawn before the vote, usually because management agreed in advance to respond positively to the requests made).

146 ibid 10.

${ }^{147}$ Investor Network on Climate Risk, 'Investors Achieve Major Company Commitments on

Climate Change' (20 August 2008), at <http://www.incr.com/Page.aspx?pid=227>.

148 ibid.

149 As evident in the work of the UK-based IIGCC, at <http://www.iigcc.org >.

150 SIF, above (n 145) 22.

${ }^{151} \mathrm{C}$ Williams and J Conley 'Corporate Social Responsibility in the International Context: Is there an Emerging Fiduciary Duty to Consider Human Rights?' (2005) 74 University of Cincinnati Law Review 75, 96.

152 D Cogan, Unexamined Risk: How Mutual Funds Vote on Climate Change Shareholder Risk (CERES, Boston, 2006) 299. 
management. While from an investment perspective we may consider how a company's social and political practices may affect present and prospective valuations and returns, we believe that proposals which prohibit companies from lines of business for social or political reasons are often motivated by narrow interest groups and not in the best interest of the broad base of shareholders of a company. We believe that management is in the best position to determine these fundamental business questions. We will typically vote against such proposals. $^{153}$

While the proxy voting record reforms in the US now require mutual funds to disclose publicly their voting policies and actual voting records, some preliminary research suggests it has not generated significant changes in the industry. $^{154}$

The US Securities Exchange Commission (SEC) has arbitrated over many shareholder resolutions on climate change disputed by the targeted companies. ${ }^{155}$ The SEC has tended to rule against resolutions if they raise 'ordinary business' issues deemed a prerogative of management. ${ }^{156}$ The SEC, however, has sometimes appeared to view such issues differently. In April 2003, the SEC allowed Xcel Energy to exclude a shareholder request for an evaluation of climate change risks to the market competitiveness of the company. ${ }^{157}$ Yet, in March 2005, the SEC allowed a shareholder demand on ExxonMobil to 'undertake a comprehensive review and publish a report on how it will meet the greenhouse gas reduction targets of those countries in which it operates which have adopted the Kyoto Protocol'. ${ }^{158}$ The SEC rejected the claim of ExxonMobil's management that the shareholders' request amounted to an attempt to micro-manage the business.

To date, although shareholder resolutions on climate change issues are relatively scarce compared to traditional subjects of shareholder proposals (such as executive pay), climate change as a subject garners more shareholder proposals than virtually any other environmental cause on the SRI agenda. ${ }^{159}$ Further, targeted companies may concede to shareholder demands even if a proposal is defeated in a vote. Thus, Ford Motor Company agreed to implement a defeated resolution that asked it to report on the business implications of reducing GHG emissions from its vehicles and manufacturing

153 Cited in Cogan, ibid 28.

154 M Cremers and R Romano, 'Institutional Investors and Proxy Voting: The Impact of the 2003 Mutual Fund Voting Disclosure Regulation', ECGI-Law Working Paper No 083/2007 (Social Science Research Network, 24 April 2007) 2-3.

${ }^{155}$ For a more detailed discussion, see S Choi, 'It's Getting Hot in Here: The SEC's Regulation of Climate Change Shareholder Proposals Under the Ordinary Business Exception' (2006) 17 Duke Environmental Law and Policy Forum 165.

156 ibid 178-79.

157 Xcel Energy, 'SEC No-Action Letter, 2003', Lexis 500 (April 1, 2003) 1.

158 ExxonMobil Corporation, 'SEC No-Action Letter, 2005', Lexis 466 (March 23, 2005) 1.

159 SIF, above (n 145) 19 (only shareholder proposals on political contributions were more numerous among US investors in 2005). 
facilities. ${ }^{160}$ In all respects, however, the focus of shareholder activism on climate change and any corporate response is strictly the business implications of climate change.

\section{REFLECTIONS AND FUTURE DIRECTIONS}

Climate finance is an essential part of the solution to global warming. So far, most policy-makers and commentators have focused on the transactional side of the financial sector, viewing investment institutions as mere brokers or passive financiers of measures to mitigate or adapt to climate change. The potential role of the financial sector as a means to stimulate far-reaching changes in corporate behaviour through the example set by the long-standing movement for SRI is only just starting to be seriously explored.

Certainly, in the financial sector there is growing awareness of climate change as a threat to investment portfolios or as an opportunity to enhance returns. Yet, even from this pragmatic business case approach to SRI, in various ways investors remain hampered in dealing with global warming. ${ }^{161}$ They may believe that climate change is too remote to affect a company's bottom line, or that there are seemingly more pressing issues affecting investment values. Another hindrance is the difficulties of determining the implications of climate change, and government policy responses to it, for financial markets. For instance, there is insufficient research demonstrating the relationship between GHG emission regulations and investment returns. Basic data may also be too imprecise for practical decisions. The present lack of intergovernmental agreement on GHG emission targets beyond 2012, when the Current Kyoto Protocol commitment period expires, also obstructs setting a durable value on carbon reduction and climate adaptation measures.

We can discern two important insights from this exploration of climate finance. First, in an acknowledgement of the limits of current approaches, the World Business Council for Sustainable Development concedes that the transition to a low carbon economy requires government policy instruments to send the correct economic signals. ${ }^{162}$ The market has struggled to capture and reflect climate risks efficiently. These failures mean that financing renewable energy supplies and energy efficiency technologies 'generally entail higher risks and initial costs than conventional projects'. ${ }^{163}$ Government policies

160 Ford published its report on 2005, and claimed to have reduced carbon emissions from its manufacturing facilities by 15 per cent, with further reductions planned, and was adopting measures to improve the fuel efficiency of its cars: Ford Motor Company, Ford Report on the Business Impact of Climate Change (Ford, Dearborn, Michigan, 2005 ) 3.

${ }_{161}$ Innovest, Climate Change and the Financial Services Industry. Module 2-A Blueprint for Action (UNEPFI, Geneva, 2002) 31-34.

${ }_{162}$ World Business Council for Sustainable Development (WBCSD), Energy and Climate Change: Sharpening the Focus for Action-A Business Perspective (WBCSD, Geneva, 2005).

${ }_{163}$ See Z Zhang and A Maruyama, 'Towards a Private-Public Synergy in Financing Climate Change Mitigation Projects' (2001) 29 Energy Policy 1363. 
must therefore set a long-term value for carbon if the SRI market driven solely by the business case is to be a force for change. Already, regulation and litigation risks are major drivers for financiers to factor climate change into their investment choices. The prospect of carbon emission caps, carbon taxes, renewable energy subsidies, and mandatory corporate disclosures on climate impacts-imposed by governments-are becoming crucial for the SRI market on climate finance. This fact should remind us of how heavily SRI often depends on market regulation. In this sense, SRI presents a paradox, having emerged as a form of surrogate market regulation to compensate for the lacunae of official regulation, yet often heavily dependent on the state to set environmental standards necessary to stimulate the SRI market.

A second key insight is that the ethical issues posed by climate change have been poorly acknowledged in the SRI movement (let alone by financial markets generally). The business case approach to SRI, even at its most efficient, will probably never be a satisfactory solution because it rests on perpetuating the same economic system premised on infinite growth that has wrought so much ecological damage. There must surely also be an ethical envelope to climate finance, providing a normative framework for restraint to safeguard ecological integrity and ensure social justice in entitlements to use limited environmental resources.

Climate change is very much an ethical issue, as humankind's ability to tamper with the earth's climate should raise profound questions about our relationship with nature. ${ }^{164}$ Indeed, the UNFCCC proclaims as one of its core principles that: ' $[\mathrm{t}]$ he Parties should protect the climate system for the benefit of present and future generations of humankind, on the basis of equity and in accordance with their common but differentiated responsibilities and respective capabilities'. ${ }^{165}$ Further, the question of who should shoulder the primary burden of addressing climate change raises significant ethical questions of ensuring social and economic justice between developing and developed countries. ${ }^{166}$ But the financial sector has been able to bypass such uncomfortable questions that would raise doubts about the sustainability and justice of our economic system. Instead, the climate finance discourse has been carefully framed around business risks and investment opportunities. There is nothing objectionable to investors financially benefiting from reducing their carbon footprint. The problem is that the business case will not always provide sufficient motivation for change.

Such conclusions, of course, raise questions regarding what policy-makers could do to make ethically-driven SRI on climate change more widespread in financial markets. While the answer requires another article of much longer

164 P Taylor, 'The Business of Climate Change: What's Ethics Got to Do With It?' (2007), 20 Global Business and Development Law Journal 161.

165 Article 3.1 (1992) 31 ILM 849.

166 See L Rajamani, Differential Treatment in International Environmental Law (Oxford University Press, 2006). 
length, a few concluding comments can be briefly made. As a priority, reformers should target the fiduciary duties of investment institutions, for these provide the very core legal standards that determine their basic economic goals. One option would be to mandate the goal of sustainable development, as the overall benchmark to hold financial investment to account. Thereby, the fiduciary obligation to promote private returns must take into account their public costs. But such a fiduciary standard must be underpinned by concrete performance standards if it is to be workable. Vague stipulations to 'promote sustainability' would not suffice. They would likely be undermined by discretionary interpretations on which financiers could not be legally challenged. The advances in designing sustainable performance indicators in environmental policy-making should be extended to financial investments. ${ }^{167}$ One such indicator is the carbon footprint of an investment portfolio-one of the most powerful indicators of environmental performance. ${ }^{168}$ It would surely also be necessary to democratize decision-making in financial institutions, giving more voice to ordinary fund members as well as to outside third parties affected by their investments. This should enable other social values to be considered in investment policies. Given the global scale of modern financial markets, parallel reforms to fiduciary duties and investment decision-making must be etched into new international legal rules governing cross-border finance. The existing range of voluntary international standards such as the UNPRI and the Climate Principles fall short of meeting the exacting standards required. The current intergovernmental climate change negotiations could provide a suitable forum to introduce some climate finance standards into international climate law.

In sum, while SRI suggests a more ambitious and enlightened role for financial institutions on climate change issues, so far the SRI sector has made a fairly limited and largely uninspiring contribution. SRI can not yet provide a credible alternative to official regulation, but it could make a more useful contribution with appropriate enabling legal reforms.

$167 \mathrm{~J}$ Keeble, S Topiol and S Berkeley, 'Using Indicators to Measure Sustainability Performance at a Corporate and Project Level' (2003) 44 Journal of Business Ethics 149; O Schmid-Schönbein and A Braunschweig, EPI-Finance 2000; Environmental Performance Indicators for the Financial Industry (E2 Management Consulting AG, Zürich, 2000).

${ }^{168}$ Carbon footprints of investment portfolios are already been measures: Trucost, Carbon Counts 2007: The Carbon Footprint Ranking of UK Investment (Trucost, London, 2007). 